\title{
Rancang Bangun Sistem Pakar Diagnosis Penyakit Kucing Menggunakan Metode Backward Chaining
}

\author{
Rahmat Haryadi Kiswanto ${ }^{1}$, Satya Bakti², Rosiyati M.H. Thamrin ${ }^{3}$ \\ Program Studi Teknik Informatika \\ STIMIK Sepuluh Nopember Jayapura \\ Jayapura, Indonesia \\ e-mail: ${ }^{1}$ kissonetwo74@gmail.com, ${ }^{2}$ satyagamer89@gmail.com, ${ }^{3}$ rosiyati.thamrin@yahoo.com \\ Diajukan: 6 September 2021; Direvisi: 1 Desember 2021; Diterima: 3 Desember 2021
}

\begin{abstract}
Abstrak
Kucing merupakan hewan yang cukup banyak dipelihara oleh manusia. Sebagai hewan peliharaan kucing perlu mendapat perhatian perawatan yang cukup baik dari pemiliknya terlebih dalam hal kesehatannya. Banyak dari pemilik kucing tidak tahu gejala penyakit pada hewan ini, sehingga sering terjadi keterlambatan penanganan, pencegahan ataupun pengobatan pada kucing karena ketidaktahuan akan gejala sakit pada kucing. Sistem Pakar adalah sistem yang mengadopsi kemampuan pakar yang dituangkan ke dalam komputer agar komputer dapat berpikir dan memutuskan hasil layaknya seorang pakar. Penelitian ini bertujuan untuk membuat sistem pakar diagnosis penyakit kucing berdasarkan gejala yang muncul dengan menggunakan Metode Backward Chaining sebagai inference Engine. Data penyakit, gejala penyakit dan penanganannya diperoleh dari laboratorium Veteriner dan Puskeswan kota Jayapura, kemudian kepakaran penyakit hewan diperoleh dari dokter hewan di Laboratorium tersebut. Sistem pakar yang dibangun berhasil mengimplementasikan metode Backward Chaining untuk mengadopsi kepakaran dokter hewan untuk 9 jenis penyakit yaitu Scabies, Ektoparasit, Endoparasite, Babesiosis, Suspect Calicivirus, Suspect Panleukopenia, Suspect Chlamydia,Stomatitis, dan Helminthiasis. Metode Black Box digunakan untuk menguji fungsionalitas sistem dan dilakukan dengan melihat kesesuaian hasil yang diharapkan dengan hasil uji dan diperoleh tingkat kesesuaiannya 100\% .
\end{abstract}

Kata kunci: Sistem Pakar, Penyakit kucing, Gejala penyakit.

\begin{abstract}
Cats are animals that are pretty much kept by humans. As a pet, they needs to get more care from its owner, especially its health. Many cat owners did not know the cat disease symptoms, so there are often delays in handling, preventing or treating cats due to ignorance of the symptoms. The Expert System is a computer system that adopts expert abilities that allows the computer to think and decide results like an expert. This study aims to create an expert system for diagnosing cat diseases based on symptoms using the backward chaining method as an inference Engine. Data on disease, disease symptoms, and their treatment were obtained from the Veterinary Laboratory and Puskeswan in Jayapura City, and the expertise was obtained from the veterinarian. The expert system was built successfully implemented backward chaining method to adopt the veterinarians expertise for 9 types of disease that were scabies, ectoparasites, endoparasites, babesiosis, suspect calicivirus, suspected panleukopenia, suspected chlamydia, stomatitis, and helminthiasis. The black box method was used to test the system functionality by looking at the conformity level of the desired results to the test results and obtained a conformity level of 100\%.
\end{abstract}

Keywords: Expert System, Cat Disease, Disease Symptoms.

\section{Pendahuluan}

Kucing merupakan hewan yang cukup banyak dimiliki oleh manusia sebagai hewan peliharaan. Hewan peliharaan ini sangat disukai oleh manusia karena kucing merupakan hewan yang memiliki banyak kelebihan. Bulunya lembut, bentuk tubuhnya menggemaskan, sifatnya yang manja selalu membuat manusia suka membelai dan bermain dengannya. Selain itu, tingkah laku kucing yang sangat lucu saat bercanda membuat pemiliknya terhibur. Awalnya kucing berasal dari alam liar, kemudian perlahan-lahan menjalani proses domestikasi. Kini, kucing menjadi hewan peliharaan yang sangat dekat dengan manusia [1]. 
Balai laboratorium Veteriner dan Puskeswan Jayapura merupakan tempat penanganan, pengendalian, dan/atau pemusnahan penyakit menular maupun tidak pada hewan. Balai ini menangani kasus hewan yang sakit dan rata-rata per tahun dalam 3 tahun terakhir jumlah pasien yang diperiksa sekitar 68 hewan. Di antara jumlah pasien yang diperiksa adalah hewan kucing peliharaan. Permasalahan yang terjadi adalah hewan kucing yang dibawa ke balai laboratorium ini kondisinya sudah cukup parah, sehingga dapat dikatakan bahwa pemilik hewan peliharaan kucing ini kurang memahami gejala dan apa yang harus dilakukan terhadap kucing yang sakit. Selain dari itu balai ini juga belum ada fasilitas untuk rawat inap terhadap hewan yang sakit, sehingga masih dilakukan dengan rawat jalan.

Kurangnya pengetahuan pemilik kucing terhadap gejala sakit dan penanganan terhadap kucing yang sakit, maka tindakan secara dini tidak dapat dilakukan oleh pemiliknya. Penelitian yang dilakukan ini mencoba memberikan sebuah solusi kepada para pemilik hewan kucing dengan membangun sebuah sistem pakar berbasis komputer dengan menggunakan metode Backward Chaining yang dapat memberikan informasi jenis penyakit dan penanganannya sehingga pemilik dapat sedini mungkin mengetahui gejala yang diderita kucing peliharaannya dan dapat mengambil tindakan lanjutan apakah perlu ke dokter hewan atau tidak .

Sistem pakar adalah perangkat lunak yang dirancang khusus berbasis Artificial Intelligence, di mana sistem mengadopsi pengetahuan manusia ke komputer sehingga komputer dapat memecahkan suatu masalah tertentu dengan meniru pekerjaan pakar[2]. Melalui sistem berbasis komputer, analisis-analisis dapat dilakukan dengan cepat walaupun melalui tahapan-tahapan yang ada.

Beberapa penelitian yang pernah dilakukan terkait objek maupun metode yang digunakan dalam penelitian ini di antaranya, penelitian sistem pakar diagnosis penyakit kucing menggunakan metode CaseBased Reasoning [3], penelitian ini memiliki objek yang lebih spesifik yaitu kucing Persia dan menggunakan metode yang berbeda. Selanjutnya penelitian tentang penyakit kulit pada kucing menggunakan metode Forward Chaining [4], pada penelitian ini fokus pada penyakit kulit pada kucing yang menyebabkan kerontokan bulu, sistem yang dibangun berbasis android. Kemudian penelitian tentang penerapan sistem pakar dalam upaya meminimalisir risiko penularan penyakit kucing [5], penelitian ini fokus pada pencegahan penularan penyakit kucing dan metode yang digunakan adalah metode Forward Chaining. Penelitian berikutnya adalah penelitian sistem pakar diagnosis penyakit pada kucing [6], penelitian ini mempunyai objek yang sama tetapi metode yang digunakan adalah metode Naïve Bayes Classifier dan penelitian ini dilakukan melihat para pemilik kucing terkendala dari sisi ekonomi, kesibukan dan tidak semua tempat ada dokter hewan sehingga memberikan solusi pembangunan sistem pakar berbasis web sehingga pemilik dapat sedini mungkin mengetahui jika ada gejala-gejala sakit terhadap kucing peliharaannya. Penelitian lainnya yang dilakukan oleh [7] tentang sistem pakar diagnosis penyakit kucing menggunakan metode Naïve Bayes - Certainty Factor, penelitian ini diteliti melihat dari keterbatasan dokter hewan dalam melakukan diagnosis penyakit kucing, sehingga diperlukan sistem yang dapat mendiagnosis dengan cepat dan tepat berdasarkan rekam medis sebelumnya.

Berdasarkan penelusuran pustaka yang telah dilakukan terkait dengan objek dan metode yang pernah dilakukan sebelumnya, maka pada penelitian yang dilakukan ini objek yang diteliti disebabkan oleh parasit dengan metode yang digunakan adalah metode Backward Chaining. Lokasi penelitian dilakukan di Balai Laboratorium Veteriner dan Puskeswan kota Jayapura.

\section{Metode Penelitian}

\subsection{Desain Penelitian}

Desain penelitian yang digunakan adalah ex post facto yang fokus pada penyelidikan pada apa yang sebenarnya telah terjadi. Pengumpulan data dilakukan dengan cara studi pustaka, observasi dan wawancara dengan pihak terkait. Studi pustaka dilakukan untuk mendapatkan teori-teori dan menelaah penelitian-penelitian yang berkaitan dengan sistem pakar dan metode yang digunakan untuk membandingkan dan menghindari terjadinya duplikasi-duplikasi pada penelitian. Observasi dilakukan untuk melihat gambaran nyata pada proses yang terjadi, sedangkan wawancara dilakukan terhadap pihak laboratorium dalam hal ini dokter hewan selaku pakar penyakit hewan untuk melengkapi data pengetahuan dan mendukung hasil observasi. Agar penelitian ini dapat berjalan dengan baik maka perlu dibuat suatu rancangan tahapan penelitian. Tahapan penelitian menggunakan model pengembangan Waterfall yang dapat dilihat pada Gambar 1. 


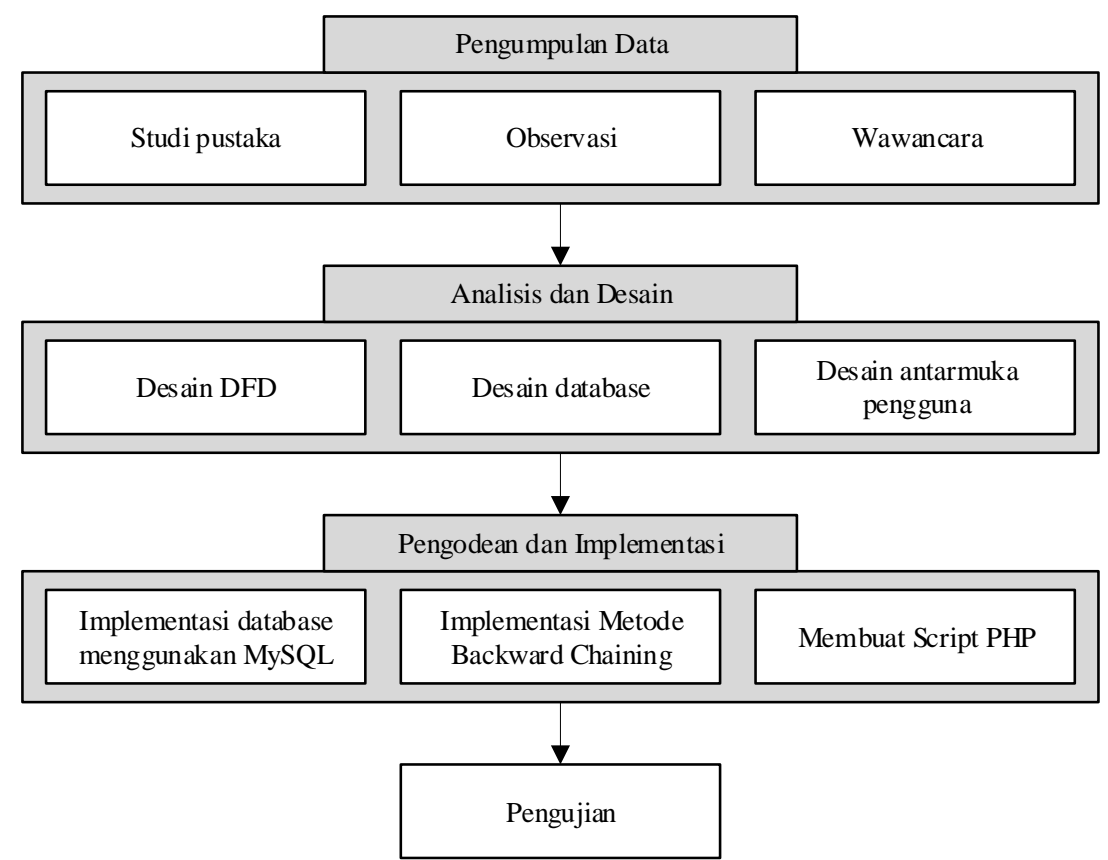

Gambar 1. Tahapan Penelitian.

\subsection{Backward Chaining}

Backward Chaining merupakan metode penalaran kebalikan dari forward chaining. Proses ini mirip dengan pengujian hipotesis dalam pemecahan masalah manusia [8]. Misalnya, seorang dokter mungkin mencurigai beberapa masalah dengan pasien, yang kemudian ia coba buktikan dengan mencari gejala-gejala tertentu. Backward Chaining akan mencari rule inferensi sampai menemukan aturan di mana mempunyai suatu klausa THEN yang cocok dengan goal yang diinginkan. Jika klausa IF dari aturan inferensi itu diketahui tidak benar, maka akan ditambahkan ke daftar tujuan (agar tujuan dikonfirmasi, itu juga harus menyediakan data yang mengkonfirmasi aturan baru ini). Metode ini akan mencari aturan yang dapat menyimpulkan informasi yang dibutuhkan oleh tujuan, dan mencoba membuat bagian-bagian dari aturan-aturan itu terpenuhi. Backward Chaining ini mengadopsi model pencarian Depth-First [9]. Secara sederhana gambar alur Backward Chaining penyakit kucing pada penelitian ini dapat dilihat pada Gambar 2

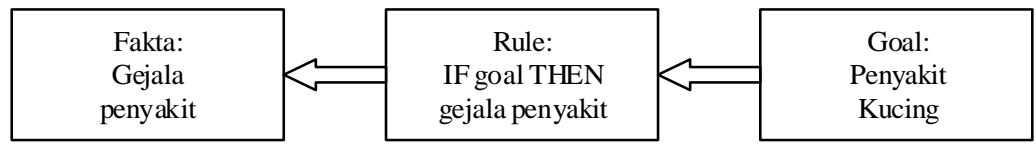

Gambar 2. Backward Chaining Penyakit Kucing.

\subsection{Dasar Pengetahuan}

Dasar pengetahuan dalam penelitian ini berupa data jenis penyakit, gejala, penanganan, pencegahan dan rule penyakit.

A. Data Gejala, Jenis Penyakit, dan Rule

Tabel 1,2,3 dan 4 merupakan data yang digunakan dalam penelitian dan ditandai dengan identitas pengenal (id) dan akan digunakan untuk membangun sistem pakar. Daftar gejala dapat dilihat pada Tabel 1.

Tabel 1. Daftar Gejala.

\begin{tabular}{cl}
\hline ID & Gejala \\
\hline G001 & Bulu Rontok \\
\hline G002 & Suka Menggaruk Badan \\
\hline G003 & Kulit Kemerahan dan Berkerak (area jari dan daun telinga) \\
\hline G004 & Ditemukan Kutu; Caplak; Pinjal \\
\hline G005 & Nafsu Makan Berkurang \\
\hline G006 & Diare \\
\hline
\end{tabular}

Rancang Bangun Sistem Pakar Diagnosis Penyakit Kucing Menggunakan Metode Backward Chaining (Rahmat Haryadi Kiswanto) 


\begin{tabular}{ll}
\hline ID & Gejala \\
\hline G007 & Muntah \\
\hline G008 & Lesu \\
\hline G009 & Lemas \\
\hline G010 & Konjungkiva pucat \\
\hline G011 & Bulu Kasar \\
\hline G012 & Kelenjar Getah Bening Membesar \\
\hline G013 & Ditemukan Caplak \\
\hline G014 & Bersin, Keluar Leleran Hidung \\
\hline G015 & Mata Berair dan Bengkak \\
\hline G016 & Demam \\
\hline G017 & Dehidrasi \\
\hline G018 & Disertai Darah pada Feses \\
\hline G019 & Bersin dan Batuk \\
\hline G020 & Sesak Nafas \\
\hline G021 & Keluar Air Liur Belebihan \\
\hline G021 & Gusi Berdarah \\
\hline G022 & Bau Mulut \\
\hline G024 & BAB Menurun \\
\hline G025 & BAB Encer \\
\hline
\end{tabular}

Tabel 2. Daftar Jenis Penyakit.

\begin{tabular}{cl}
\hline ID & \multicolumn{1}{c}{ Jenis Penyakit } \\
\hline P01 & Scabies \\
\hline P02 & EktoParasit \\
\hline P03 & EndoParasit \\
\hline P04 & Babesiosis \\
\hline P05 & Suspect Calicivirus \\
\hline P06 & Suspect Panleukopenia \\
\hline P07 & Suspect Clamydia \\
\hline P08 & Stomatitis \\
\hline P09 & Helminthiasis \\
\hline
\end{tabular}

B. Relasi Jenis Penyakit, Gejala,

Tabel 3 merupakan relasi/hubungan antara gejala dan penyakit yang ditandai dengan tanda $\mathbf{X}$.

Tabel 3. Relasi Gejala dan Penyakit.

\begin{tabular}{|c|c|c|c|c|c|c|c|c|c|}
\hline ID & P01 & P02 & P03 & P04 & P05 & P06 & P07 & P08 & P09 \\
\hline G001 & $\mathrm{X}$ & $\mathrm{X}$ & & & & & & & \\
\hline G002 & $X$ & $X$ & & & & & & & \\
\hline G003 & $\mathrm{X}$ & & & & & & & & \\
\hline G004 & & $X$ & & & & & & & \\
\hline G005 & & & $\mathrm{X}$ & $\mathrm{X}$ & $X$ & $\mathrm{X}$ & & $\mathrm{X}$ & $X$ \\
\hline G006 & & & $X$ & & & $X$ & & & \\
\hline G007 & & & $X$ & $\mathrm{X}$ & & $X$ & & & $X$ \\
\hline G008 & & & $X$ & $X$ & & $X$ & & & \\
\hline G009 & & & $X$ & $X$ & & & & & \\
\hline G010 & & & $X$ & $X$ & & & & & \\
\hline G011 & & & & $\mathrm{X}$ & & & & & \\
\hline G012 & & & & $X$ & & & & & \\
\hline G013 & & & & $X$ & & & & & \\
\hline G014 & & & & & $X$ & & & & \\
\hline G015 & & & & & $X$ & & $X$ & & \\
\hline G016 & & & & & $\mathrm{X}$ & & $X$ & & \\
\hline G017 & & & & & & $X$ & & & \\
\hline G018 & & & & & & $X$ & & & \\
\hline G019 & & & & & & & $X$ & & \\
\hline G020 & & & & & & & $X$ & & \\
\hline G021 & & & & & & & & $X$ & \\
\hline G022 & & & & & & & & $X$ & \\
\hline G023 & & & & & & & & $X$ & \\
\hline G024 & & & & & & & & $X$ & \\
\hline G025 & & & $X$ & & & & & & $X$ \\
\hline
\end{tabular}

Tabel 4 merupakan basis pengetahuan yang diterapkan ke dalam algoritma Backward Chaining. 
Tabel 4. Rule Basis Pengetahuan.

\begin{tabular}{ccc}
\hline ID Rule & If & \multicolumn{1}{c}{ Then } \\
\hline R01 & P01 & G001 is True, AND G002 is True, AND G003 is True \\
\hline R02 & P02 & G001 is True, AND G002 is True, AND G004 is True \\
\hline R03 & P03 & $\begin{array}{l}\text { G005 is True, AND G006 is True, AND G007 is True, AND G008 is True, AND G009 is } \\
\text { True, AND G010 is True, AND G025 is True }\end{array}$ \\
\hline R04 & P04 & $\begin{array}{l}\text { G005 is True, AND G007 is True, AND G008 is True, AND G009 is True, AND G010 is } \\
\text { True, AND G011 is True, AND G012 is True, AND G013 is True }\end{array}$ \\
\hline R05 & P05 & G005 is True, AND G014 is True, AND G015 is True, AND G016 is True \\
\hline R06 & P06 & $\begin{array}{l}\text { G005 is True, AND G006 is True, AND G007 is True, AND G008 is True, AND G017 is } \\
\text { True, AND G018 is True }\end{array}$ \\
\hline R08 & P07 & G015 is True AND, G016 is True AND, G019 is True AND, G020 is True \\
\hline R09 & P08 & G005 is True AND, G021 is True AND, G023 is True AND, G024 is True \\
\hline
\end{tabular}

\section{Hasil dan Pembahasan}

\subsection{Perancangan Sistem}

Perancangan sistem pakar yang ini menggunakan rancangan terstruktur yaitu menggunakan metode Data Flow Diagram (DFD) yang menggunakan desain model aliran data yang diperkenalkan oleh Yourdan dan Constantine. Notasi yang digunakan dalam DFD adalah external entities, processes, data flows, dan data stores. Perancangan sistem merupakan visualisasi aliran data dari kebutuhan fungsionalitas yang berkaitan dengan sistem yang dibangun.

Sistem pakar yang dibangun dimodelkan ke dalam DFD level 0 dan level 1. Pemodelan ini bertujuan untuk menampilkan proses-proses dan aliran-aliran data pada sistem, serta hubungan antara proses-proses dengan aliran-aliran data tersebut. Pada DFD level 0 di dalamnya terdapat proses mengolah akun, mengolah basis pengetahuan, mengolah data kucing dan menghasilkan diagnosis, lihat Gambar 3. Sedangkan untuk DFD level 1 adalah dekomposisi dari proses mengolah basis pengetahuan menjadi proses mengolah data penyakit, mengolah data gejala, mengolah data penanganan, mengolah data pencegahan dan mengolah data rule, pemodelan aliran data level 1 dapat dilihat pada Gambar 4.

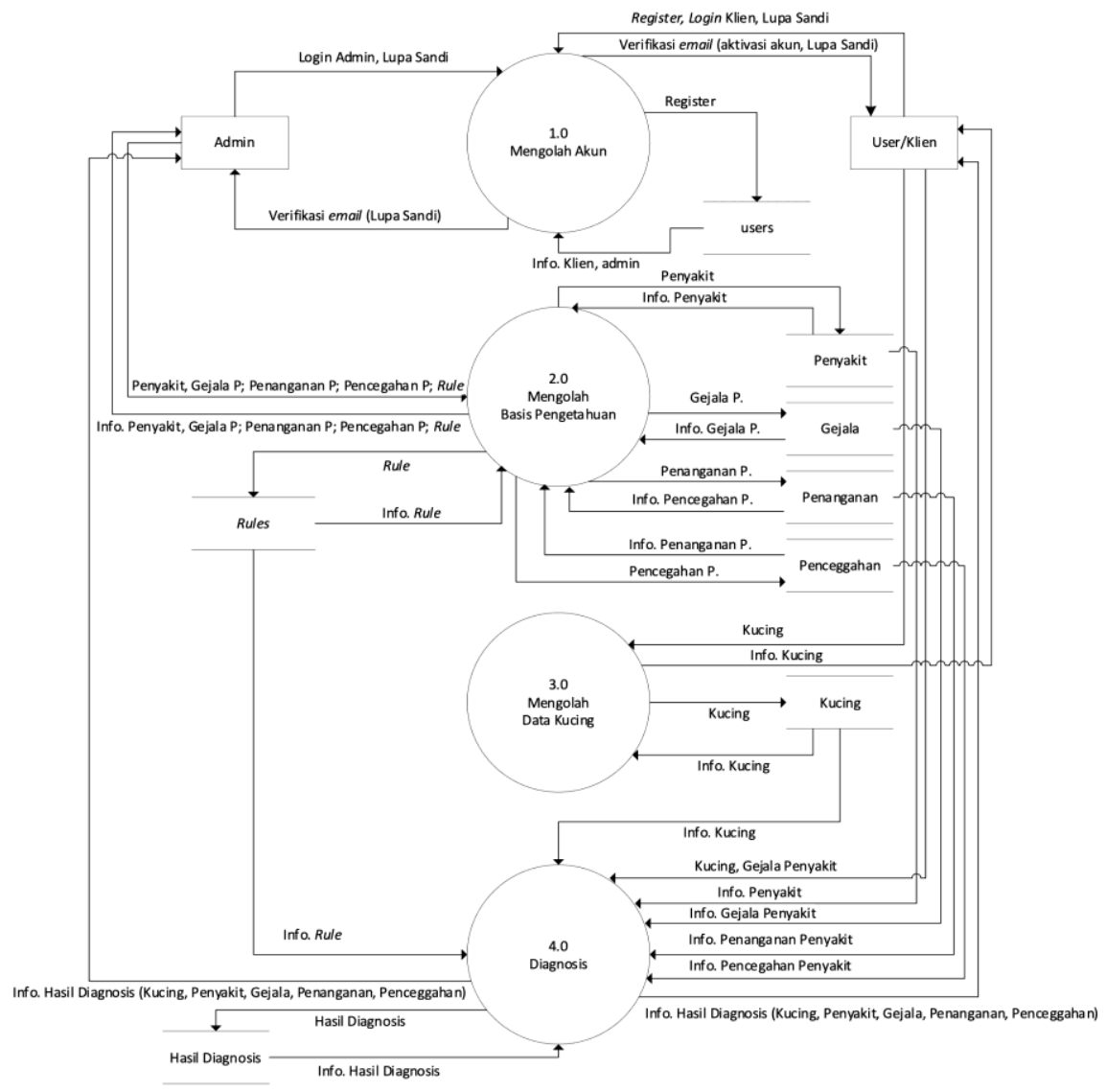

Gambar 3. DFD Level 0. 


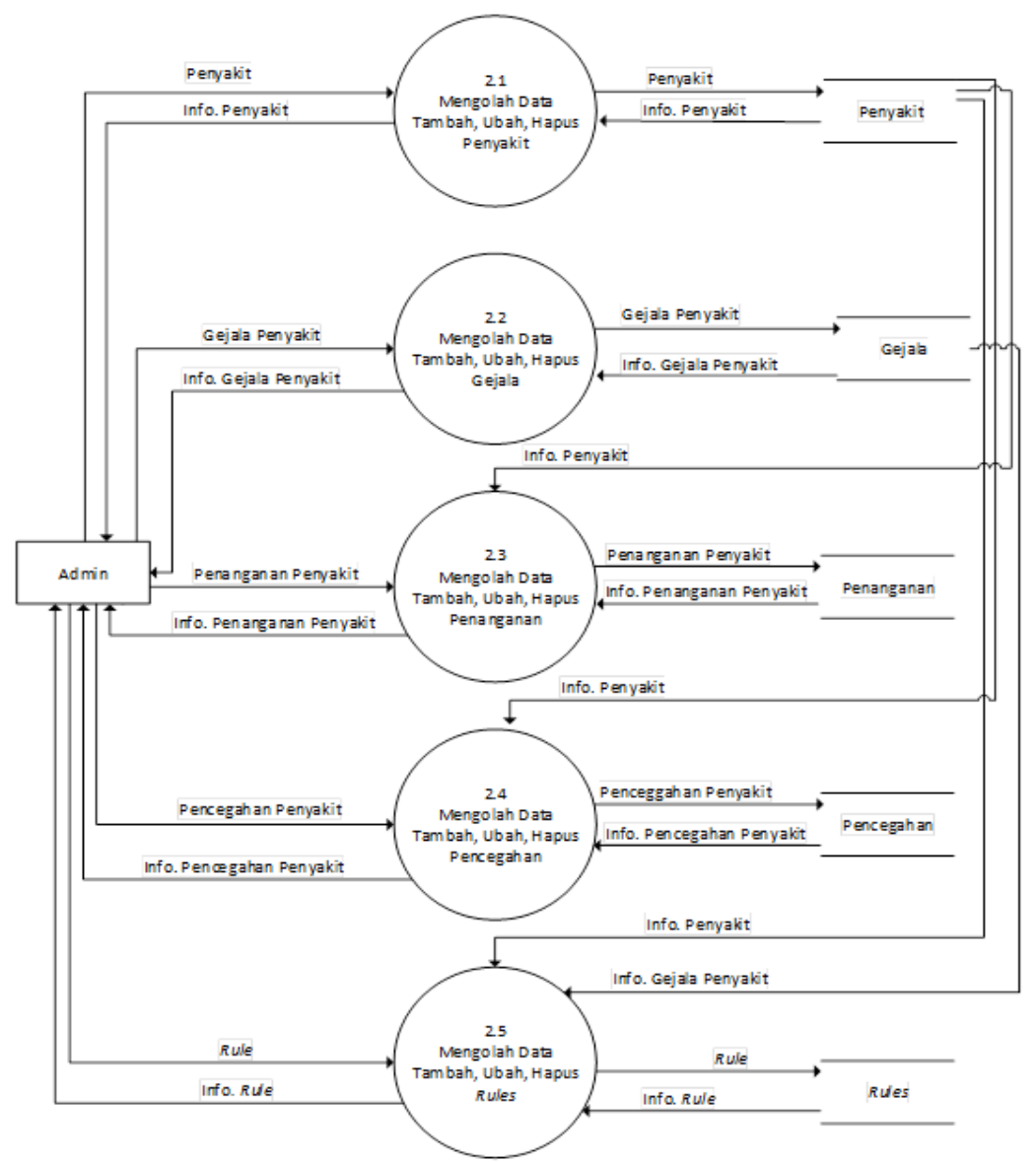

Gambar 4. Data Flow Diagram Level 1.

\subsection{Perancangan Entity Relationship Diagram (ERD)}

ERD merupakan desain skematis untuk menentukan hubungan antar entitas dalam sistem, entitasentitas ini juga dapat diidentifikasi dari rancangan DFD. ERD ini nantinya diimplementasikan ke dalam basis data dengan memilih DBMS MySQL yang digunakan dalam pembangunan sistem pakar ini. Gambar 5 merupakan rancangan ERD sistem pakar diagnosis penyakit kucing.

\subsection{Implementasi}

Hasil perancangan pada DFD dan ERD kemudian diimplementasikan ke dalam basis data serta pengodean sistem menggunakan Bahasa pemrograman PHP, Javascript, dan Bootstrap dengan menggunakan framework CodeIgniter untuk membuat tampilan antar muka, menerapkan fungsi-fungsi sistem dan mengimplementasikan metode Backward Chaining sehingga user dapat berinteraksi dengan sistem dan sistem dapat memberikan hasil sesuai dengan kepakaran dokter.

\subsubsection{Implementasi Basis Data}

Hasil perancangan pada ERD ditransformasikan dengan memilih DBMS MySQL sebagai basis data. Basis data ini digunakan untuk menyimpan data Kucing, penyakit, gejala, rule, penanganan, pencegahan, dan hasil. Gambar 6 adalah gambar implementasi database dari sistem yang dibangun menggunakan phpMyAdmin. 


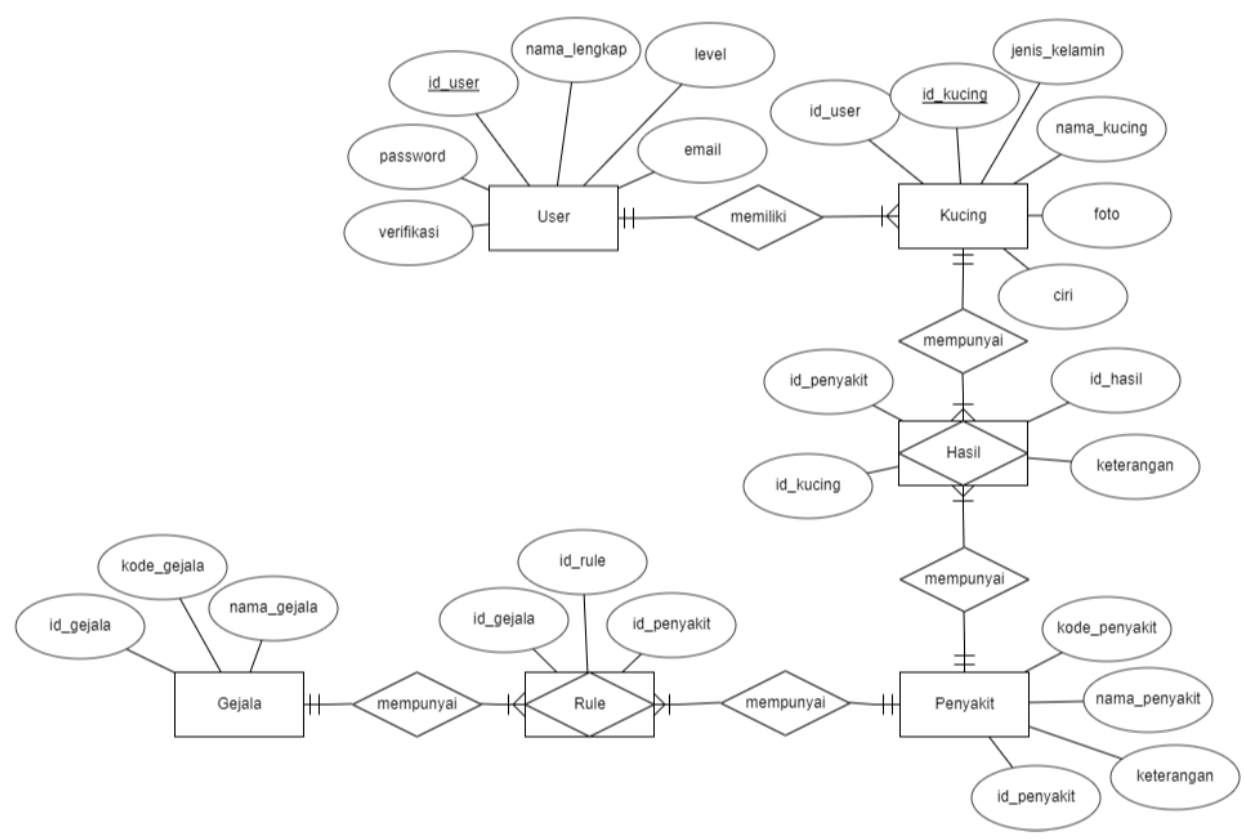

Gambar 5. Entity Relationship Diagram.

\begin{tabular}{|c|c|c|c|c|c|c|c|c|c|c|c|c|c|}
\hline & $\#$ & Nama & Jenis & Penyor & rtiran & Atribut & it Tak T & Ternilai & i Baw & vaan Komentar & & Tindakan & \\
\hline$\square$ & 1 & id_penyakit & $\operatorname{int}(11)$ & & & & Tidak & & Tidat & $k a d a$ & AUTO_INCREMENT & Ubah - Hapus & $\nabla$ Lainnya \\
\hline$\square$ & 2 & kode_penyakit & varchar(5) & utf8mb4 & 4_general_ci & & Tidak & & Tidak & $k$ ada & & Ubah $\rightarrow$ Hapus & $\nabla$ Lainnya \\
\hline$\square$ & 3 & nama_penyakit & it $\operatorname{varchar}(50)$ & ) utf8mb4 & 4_general_ci & & Tidak & & Tidak & $k$ ada & & Ubah $\odot$ Hapus & $\nabla$ Lainnya \\
\hline$\square$ & 4 & keterangan & text & utf8mb4 & 4_general_ci & & Tidak & & Tidah & $k$ ada & & Ubah $\odot$ Hapus & $\nabla$ Lainnya \\
\hline & $\#$ & Nama & Jenis & Penyortir & iran & tribut & Tak Te & ernilai & Bawa & aan Komentar E & Ekstra & Tindakan & \\
\hline$\square$ & 1 & id_gejala & $\operatorname{int}(11)$ & & & & Tidak & & Tidak & ada & AUTO_INCREMENT & Ubah $\odot$ Hapus & $\nabla$ Lainnya \\
\hline$\square$ & 2 & kode_gejala & $\operatorname{varchar}(5)$ ut & utf8mb4_c & general_ci & & Tidak & & Tidak & ada & & Ubah $\odot$ Hapus & $\nabla$ Lainnya \\
\hline$\square$ & 3 & nama_gejala & text & utf8mb4_s & general_ci & & Tidak & & Tidak & ada & & Ubah $\odot$ Hapus & $\nabla$ Lainnya \\
\hline & $\#$ & Nama & Jenis $P$ & Penyorti & iran Atribut & Tak T & Ternila & ai Baw & waan & Komentar Ekst & istra & indakan & \\
\hline$\square$ & 1 & id_rule & $\operatorname{int}(11)$ & & & Tidak & & Tida & $a k$ ada & & JTO_INCREMENT & Ubah $\odot$ Hapus & $\nabla$ Lainnya \\
\hline$\square$ & 2 & id_penyakit & int(11) & & & Tidak & & Tida & ak ada & & & Ubah $\odot$ Hapus & $\nabla$ Lainnya \\
\hline$\square$ & 3 & id_gejala & $\operatorname{int}(11)$ & & & Tidak & & Tida & ak ada & & & $\checkmark$ Ubah $\odot$ Hapus & $\nabla$ Lainnya \\
\hline & $\#$ & Nama & Jenis & & Penyortiran & & Atribut & Tak Ter & rnilai $\mathrm{E}$ & Bawaan Koment & tar Ekstra & Tindakan & \\
\hline$\square$ & 1 & id_user & int(11) & & & & & Tidak & & Tidak ada & AUTO_INCREMENT & VT Ubah Hapus & $\nabla$ Lainnya \\
\hline$\square$ & 2 & nama_lengkap & $\operatorname{varchar}(50)$ & & utf8mb4_genera & ral_ci & & Tidak & & Tidak ada & & Ubah Hapus & $\nabla$ Lainnya \\
\hline$\square$ & 3 & email & $\operatorname{varchar}(50)$ & & utf8mb4_genera & al_ci & & Tidak & & Tidak ada & & Ubah $\rightarrow$ Hapus & $\nabla$ Lainnya \\
\hline$\square$ & 4 & password & $\operatorname{varchar}(50)$ & & utf8mb4_genera & al_ci & & Tidak & & Tidak ada & & Ubah $\odot$ Hapus & $\nabla$ Lainnya \\
\hline$\square$ & 5 & verifikasi & tinyint(1) & & & & & Tidak & & Tidak ada & & Ubah $\odot$ Hapus & $\nabla$ Lainnya \\
\hline$\square$ & 6 & level & enum(Admin' & ', 'User') & utf8mb4_genera & al_ci & & Tidak & & Tidak ada & & Ubah $(-)$ Hapus & $\nabla$ Lainnya \\
\hline & $\#$ & Nama & Jenis & & Penyortiran & & Atribut & Tak Ter & rnilai & Bawaan Koment & tar Ekstra & Tindakan & \\
\hline$\square$ & 1 & id_kucing & int(11) & & & & & Tidak & & Tidak ada & AUTO_INCREMENT & VT Ubah $\odot$ Hapus & $\nabla$ Lainnya \\
\hline$\square$ & 2 & id_user $\bigcirc$ ir & int(11) & & & & & Tidak & & Tidak ada & & Ubah $\odot$ Hapus & $\nabla$ Lainnya \\
\hline$\square$ & 3 & nama_kucing & $\operatorname{varchar}(50)$ & & utf8mb4_genera & ral_ci & & Tidak & & Tidak ada & & Ubah Hapus & $\nabla$ Lainnya \\
\hline$\square$ & 4 & jenis_kelamin $e$ & enum(Jantan', & 'Betina') & utf8mb4_genera & ral_ci & & Tidak & & Tidak ada & & Ubah $(-)$ Hapus & $\nabla$ Lainnya \\
\hline$\square$ & 5 & ciri & text & & utfomb4_genera & ral_ci & & Tidak & & Tidak ada & & Ubah $\rightarrow$ Hapus & $\nabla$ Lainnya \\
\hline$\square$ & 6 & foto & text & & utf8mb4_genera & ral_ci & & Tidak & & Tidak ada & & Ubah $(-)$ Hapus & $\nabla$ Lainnya \\
\hline
\end{tabular}

Gambar 6. Implementasi Basis Data Pada phpMyAdmin. 


\subsubsection{Implementasi Antarmuka Grafik}

Antarmuka grafik sistem ini juga merupakan implementasi fungsionalitas dari sistem yang diperoleh pada tahap analisis kebutuhan awal. Gambar 7 merupakan tampilan Dashboard yang mengelola data gejala , penyakit, penanganan, pencegahan, dan rule pada sistem pakar ini.

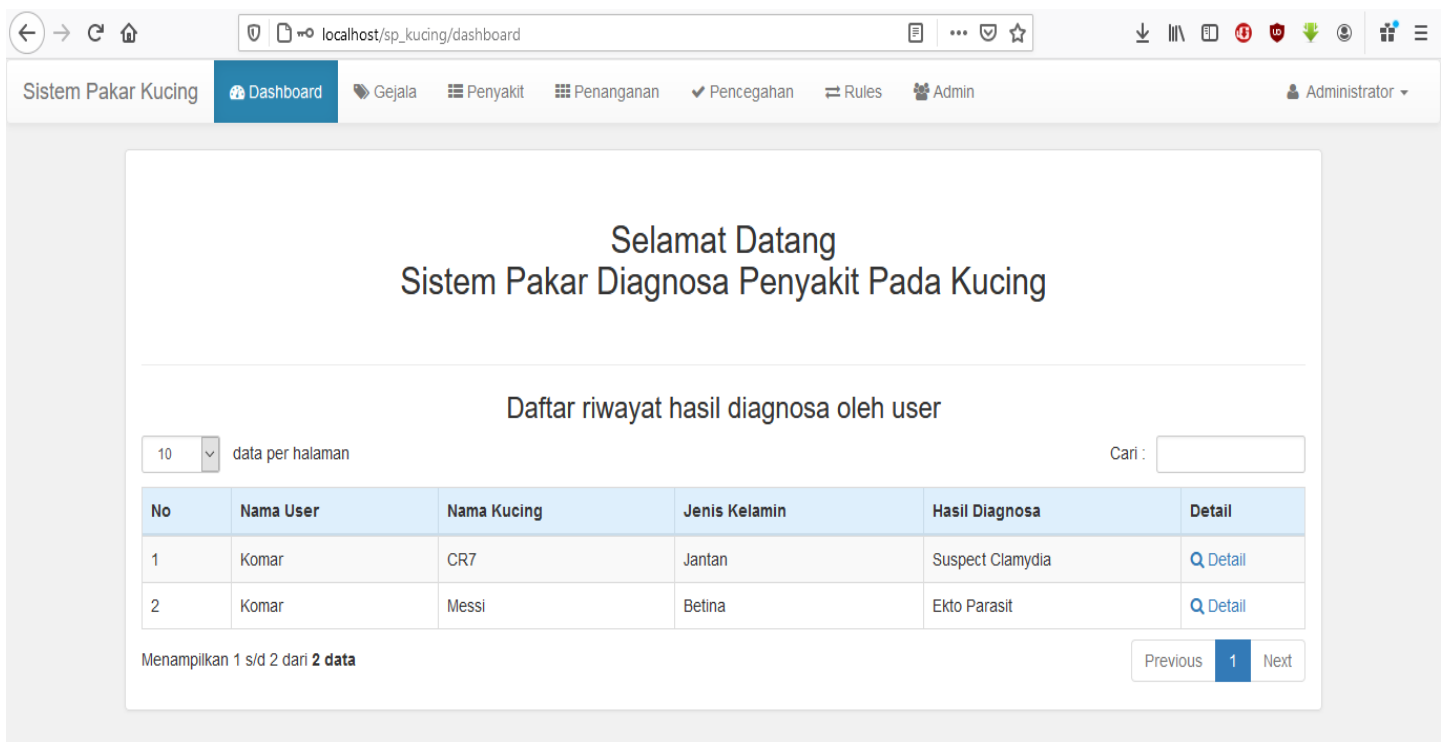

Gambar 7. Dashboard Admin.

Melalui menu rule admin dapat mengelola rule berdasarkan jenis penyakit dengan gejala-gejala yang menyertai masing-masing penyakit sehingga admin dapat menambah dan menghapus gejala pada rule berdasarkan pengetahuan yang diperoleh dari pakar. Pada gambar 8 menunjukkan halaman yang mengelola rule dari sistem pakar ini.

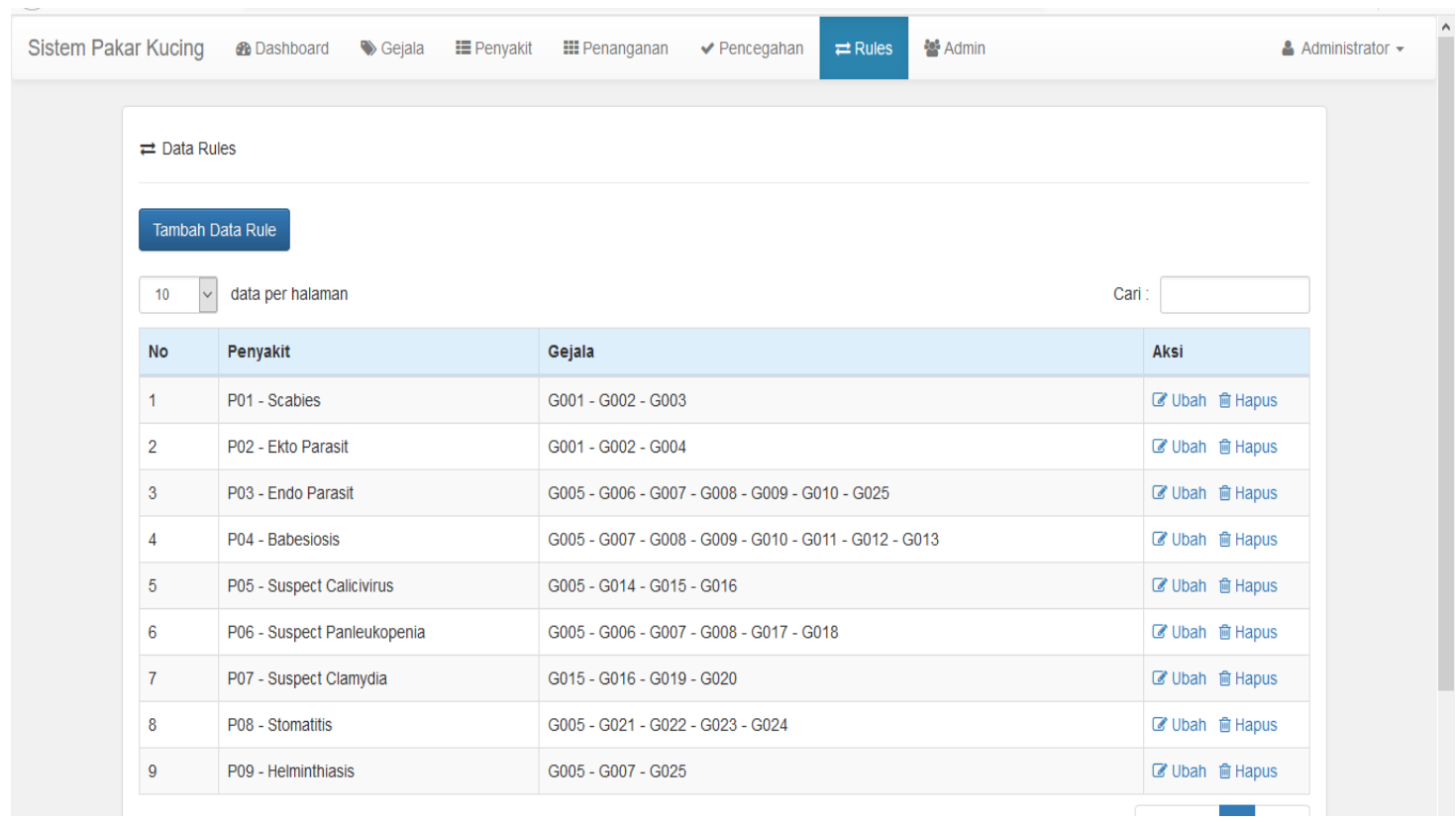

Gambar 8. Halaman Tambah Data Rule.

Tampilan antar muka untuk halaman pemilik kucing dapat dilihat pada gambar 9, kemudian gambar 9a halaman yang digunakan untuk memasukkan gejala-gejala yang terjadi berupa pertanyaanpertanyaan yang harus dijawab, selanjutnya sistem akan menampilkan halaman hasil diagnosis berdasarkan jawaban-jawaban yang diberikan, lihat gambar $9 b$. 


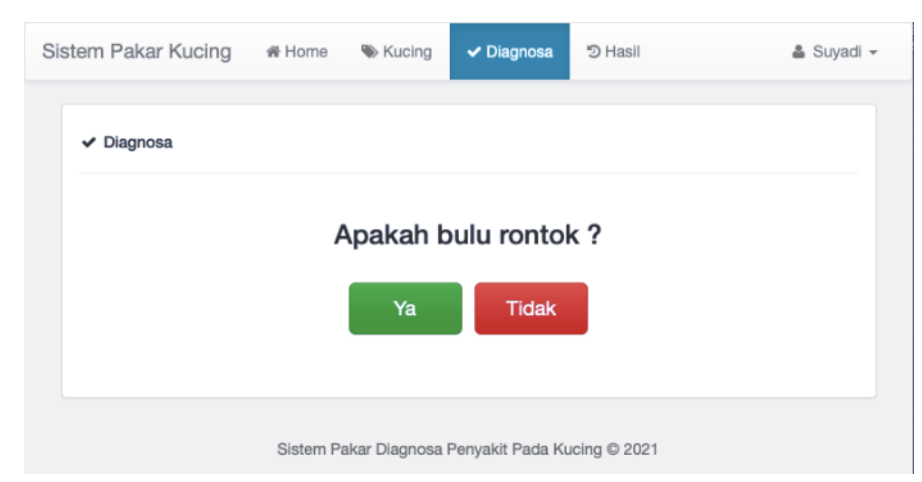

a. Halaman input gejala.

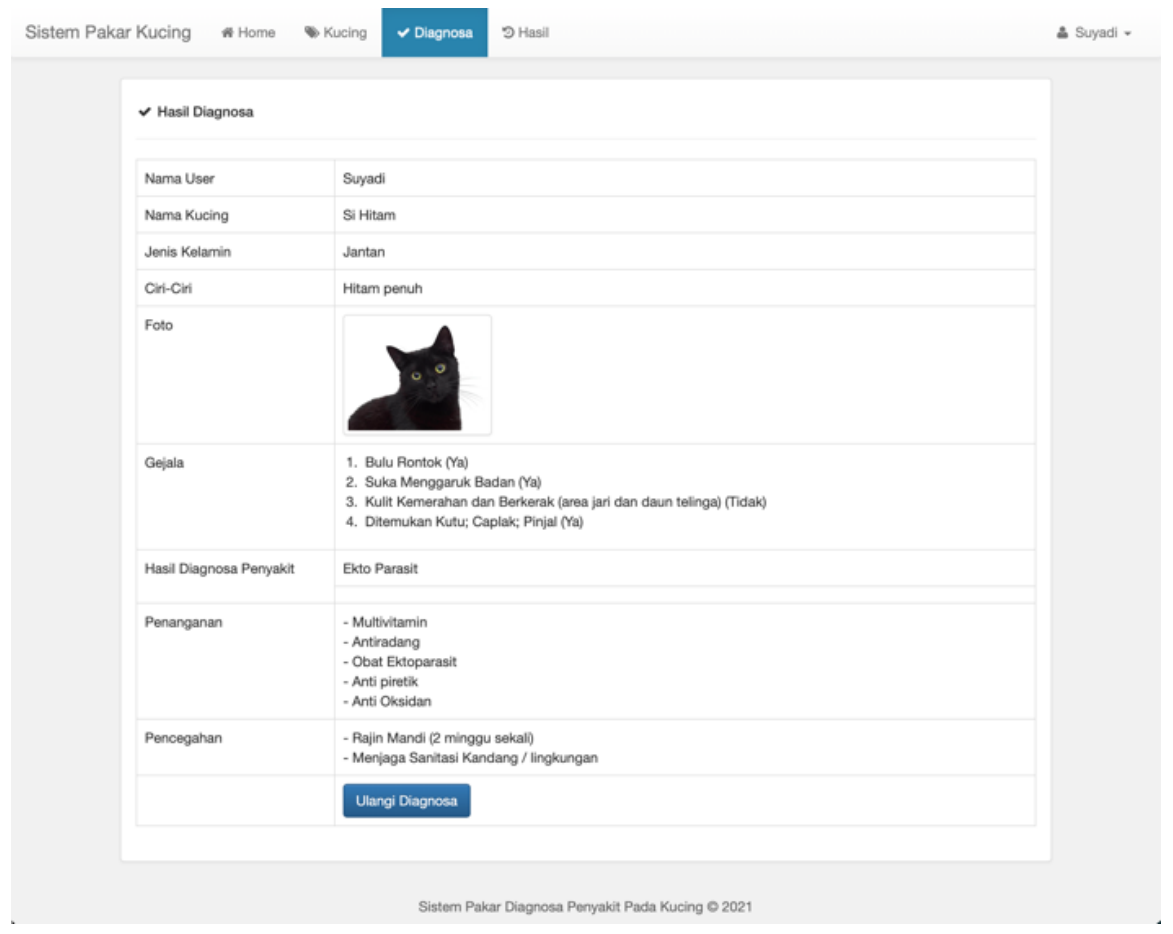

b. Halaman Hasil Diagnosis.

Gambar 9. Antarmuka Pemilik Kucing.

\subsubsection{Pengujian Program}

Aplikasi sistem pakar penyakit kucing ini berhasil dibangun, kemudian dilakukan pengujian terhadap fungsionalitas sistem apakah sudah sejalan dengan kebutuhan pengguna yang telah disepakati ditahap analisis kebutuhan, Pengujian yang dilakukan terhadap fungsionalitas sistem ini menggunakan metode blackbox. Metode blackbox merupakan pengujian berdasarkan spesifikasi kebutuhan yang tidak perlu melakukan pengujian terhadap kode program [10]. Pengujian ini fokus pada spesifikasi fungsionalitas perangkat lunak yang dibangun dengan melihat terhadap input dan ouput dari program apakah berjalan dengan benar atau tidak [11]. Tabel 5 merupakan hasil dari pengujian blackbox pada sistem pakar yang dibangun.

Tabel 5. Hasil Pengujian Blackbox

\begin{tabular}{cccccc}
\hline No. & Butir Uji & Skenario & Hasil yang diharapkan & Hasil Uji & $\begin{array}{c}\text { Valid / } \\
\text { Invalid }\end{array}$ \\
\hline 1 & Menu Register & $\begin{array}{l}\text { Daftar dengan data } \\
\text { email yang valid }\end{array}$ & $\begin{array}{l}\text { Muncul pesan verifikasi } \\
\text { akun melalui email. }\end{array}$ & $\begin{array}{l}\text { Silahkan cek email Anda untuk } \\
\text { melakukan proses verifikasi akun }\end{array}$ & Valid \\
\hline 2 & Menu Gejala & $\begin{array}{l}\text { - Tambah data } \\
\text { - Ubah data }\end{array}$ & $\begin{array}{l}\text { - Data dapat tersimpan } \\
\text { - Data dapat berubah }\end{array}$ & $\begin{array}{l}\text { - Data berhasil disimpan } \\
\text { - Data berhasil diubah }\end{array}$ & Valid \\
\hline
\end{tabular}

Rancang Bangun Sistem Pakar Diagnosis Penyakit Kucing Menggunakan Metode Backward Chaining (Rahmat Haryadi Kiswanto) 


\begin{tabular}{|c|c|c|c|c|c|}
\hline No. & Butir Uji & Skenario & Hasil yang diharapkan & Hasil Uji & $\begin{array}{l}\text { Valid / } \\
\text { Invalid }\end{array}$ \\
\hline & & - Hapus data & - Data dapa dihapus & - Data berhasil dihapus & \\
\hline 3 & Menu Penyakit & $\begin{array}{l}\text { - Tambah data } \\
\text { - Ubah data } \\
\text { - Hapus data }\end{array}$ & $\begin{array}{l}\text { - Data dapat tersimpan } \\
\text { - Data dapat berubah } \\
\text { - Data dapa dihapus }\end{array}$ & $\begin{array}{l}\text { - Data berhasil disimpan } \\
\text { - Data berhasil diubah } \\
\text { - Data berhasil dihapus }\end{array}$ & Valid \\
\hline 4 & $\begin{array}{l}\text { Menu } \\
\text { Penanganan }\end{array}$ & $\begin{array}{l}\text { - Tambah data } \\
\text { - Ubah data } \\
\text {-Hapus data }\end{array}$ & $\begin{array}{l}\text { - Data dapat tersimpan } \\
\text { - Data dapat berubah } \\
\text { - Data dapa dihapus }\end{array}$ & $\begin{array}{l}\text { - Data berhasil disimpan } \\
\text { - Data berhasil diubah } \\
\text { - Data berhasil dihapus }\end{array}$ & Valid \\
\hline 5 & $\begin{array}{l}\text { Menu } \\
\text { Pencegahan }\end{array}$ & $\begin{array}{l}\text { - Tambah data } \\
\text { - Ubah data } \\
\text {-Hapus data }\end{array}$ & $\begin{array}{l}\text { - Data dapat tersimpan } \\
\text { - Data dapat berubah } \\
\text { - Data dapa dihapus }\end{array}$ & $\begin{array}{l}\text { - Data berhasil disimpan } \\
\text { - Data berhasil diubah } \\
\text { - Data berhasil dihapus }\end{array}$ & Valid \\
\hline 6 & Menu Rules & $\begin{array}{l}\text { - Tambah data } \\
\text { - Ubah data } \\
\text {-Hapus data }\end{array}$ & $\begin{array}{l}\text { - Data dapat tersimpan } \\
\text { - Data dapat berubah } \\
\text { - Data dapa dihapus }\end{array}$ & $\begin{array}{l}\text { - Data berhasil disimpan } \\
\text { - Data berhasil diubah } \\
\text { - Data berhasil dihapus }\end{array}$ & Valid \\
\hline 7 & $\begin{array}{l}\text { Input Data } \\
\text { Kucing }\end{array}$ & $\begin{array}{l}\text { - Tambah data } \\
\text { - Ubah data } \\
\text {-Hapus data } \\
\end{array}$ & $\begin{array}{l}\text { - Data dapat tersimpan } \\
\text { - Data dapat berubah } \\
\text { - Data dapa dihapus } \\
\end{array}$ & $\begin{array}{l}\text { - Data berhasil disimpan } \\
\text { - Data berhasil diubah } \\
\text { - Data berhasil dihapus }\end{array}$ & Valid \\
\hline 8 & Menu Diagnosis & $\begin{array}{l}\text { Menjawab } \\
\text { pertanyaan }\end{array}$ & $\begin{array}{l}\text { - Menampilkan hasil } \\
\text { diagnosis }\end{array}$ & $\begin{array}{l}\text { - Berhasil menampilkan hasil } \\
\text { diagnosis }\end{array}$ & Valid \\
\hline
\end{tabular}

\section{Kesimpulan}

Sistem pakar diagnosis penyakit kucing ini dibangun berbasis web dengan hasil semua fungsionalitas sistem $100 \%$ berjalan baik berdasarkan hasil pengujian blackbox. Metode Backward Chainning yang digunakan bekerja dengan baik dan dapat menampilkan informasi penyakit kucing berdasarkan gejala-gejala yang di-input melalui pertanyaan yang ditampilkan oleh sistem. Sistem pakar ini hanya memberikan pertanyaan gejala dan informasi penyakit untuk 9 jenis penyakit kucing yaitu Scabies, Ektoparasite, Endoparasite, Babesiosis, Suspect Calicivirus, Suspect Panleukopenia, Suspect Chlamydia, Stomatis, dan Helminthiasis. Jika ada penyakit di luar 9 penyakit di atas maka gejala penyakit tersebut tidak akan ditampilkan, dan hasil diagnosis pada sistem menampilkan informasi penyakit tidak diketahui.

\section{Daftar Pustaka}

[1] A. Aulia, Y. Udjaja, I. K. Wairooy, A. P. Hutama, D. K. Shabira, and S. Muhtadin, "Android application to detect cat disease using an expert system," Adv. Sci. Technol. Eng. Syst., vol. 4, no. 5, pp. 158-162, 2019, doi: 10.25046/aj040521.

[2] C. P. C. Munaiseche, D. R. Kaparang, and P. T. D. Rompas, "An Expert System for Diagnosing Eye Diseases using Forward Chaining Method," IOP Conf. Ser. Mater. Sci. Eng., vol. 306, no. 1, 2018, doi: 10.1088/1757-899X/306/1/012023.

[3] S. Fidyaningsih, F. Agus, and D. Cahyadi, "Sistem Pakar Diagnosis Penyakit Kucing Menggunakan Metode Case-Based Reasoning," Pros. Semin. Ilmu Komput. dan Teknol. Inf. ISSN 2540 - 7902 Vol., vol. 1, no. 1, pp. 113-119, 2016.

[4] S. Nurajizah and M. Saputra, "Sistem Pakar Berbasis Android Untuk Diagnosis Penyakit Kulit Kucing Dengan Metode Forward Chaining," None, vol. 14, no. 1, pp. 7-14, 2018.

[5] O. Nurdiawan and L. Pangestu, "Penerapan Sistem Pakar dalam Upaya Meminimalisir Resiko Penularan Penyakit Kucing," InfoTekJar (Jurnal Nas. Inform. dan Teknol. Jaringan), vol. 3, no. 1, 2018, doi: 10.30743/infotekjar.v3i1.532.

[6] C. Widiyawati and M. Imron, "Sistem Pakar Diagnosis Penyakit Pada Kucing Menggunakan Metode Naive Bayes Classifier," Techno.Com, vol. 17, no. 2, pp. 134-144, 2018, doi: 10.33633/tc.v17i2.1625.

[7] A. A. S. Nugraha, N. Hidayat, and L. Fanani, "Sistem Pakar Diagnosis Penyakit Kucing Menggunakan Metode Naive Bayes - Certainty Factor Berbasis Android," J. Pengemb. Teknol. Inf. dan Ilmu Komput. Univ. Brawijaya, vol. 2, no. 2, pp. 650-658, 2018.

[8] A. Al-Ajlan, "The Comparison between Forward and Backward Chaining," Int. J. Mach. Learn. Comput., vol. 5, no. 2, pp. 106-113, 2015, doi: 10.7763/ijmlc.2015.v5.492.

[9] I. Akil, “Analisa Efektifitas Metode Forward Chaining Dan,” J. Pilar Nusa Mandiri, vol. 13, no. 1, pp. 35-42, 2017.

[10] R. H. Kiswanto, "Spesifikasi Komputer Rakitan Berdasarkan Kebutuhan dan Anggaran Menggunakan Algoritma Backtracking," J. Eksplora Inform., vol. 10, no. 1, pp. 1-12, 2020, doi: 10.30864/eksplora.v10i1.358.

[11] M. S. Mustaqbal, R. F. Firdaus, and H. Rahmadi, "Pengujian Aplikasi Menggunakan Black Box Testing Boundary Value Analysis (Studi Kasus : Aplikasi Prediksi Kelulusan SNMPTN),” vol. I, no. 3, pp. 31-36, 2015. 